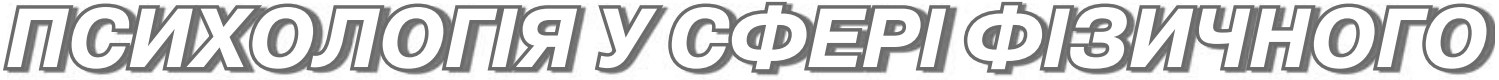 BLLYOBAMRLA I GUOPIIY
}

\section{Особливості стресостійкості у елітних спортсменів різного віку}

\section{Л. Г. Коробейнікова , Г. В. Коробейніков, Н. А. Дакал}

Київський національний університет ім. Тараса Шевченка, Київ, Україна Національний університет фізичного виховання і спорту України, Київ, Україна

\begin{abstract}
Резюме. Исследованы особенности стрессоустойчивости к психоэмоциональной нагрузке, восприятия и переработки зрительной информации у элитных спортсменов разного возраста. Обследованы 19 элитных спортсменов, членов сборной команды Украины по греко-римской борьбе. Изучены восприятие и переработка зрительной информации, баланс нервных процессов, психоэмоциональная устойчивость. Выявлена связь между возрастом элитных спортсменов и стрессоустойчивостью к психоэмоциональным нагрузкам. Установлено ухудшение нейродинамических функций в условиях психоэмоционального напряжения у спортсменов старшей возрастной группы по сравнению с младшей за счет возрастного ослабления афферентной части системы восприятия, анализа и переработки информации. Ключевые слова: стрессоустойчивость, элитные спортсмены, психоэмоциональное напряжение.
\end{abstract}

Summary. The features of psychoemotional stress load, the perception and processing of visual information in elite athletes of different ages were studied. A total of 19 elite athletes, members of the Ukrainian national team in Greco-Roman wrestling were examined. Was the studied the perception and processing of visual information, the balance of the nervous processes, psychoemotional stability. The elaborated a relationship between the age of elite athletes and psycho-emotional stress tolerance to stress. Found impairment of neurodynamics functions in an emotional stress in athletes of older age group, compared with the young, by the age of the weakening of the afferent system of perception, analysis and information processing.

Key words: tolerance to stress, elite athletes, psychoemotional stress.

Постановка проблеми. Спортивна діяльність як екстремальний різновид діяльності людини пов'язана 3 наявністю психоемоційних фракторів, що впливають на ефективність спортивного результату [1-3]. Останнє десятиріччя професійний та олімпійський спорт характеризуються зростанням вікового рівня спортсменів, які досягли високих спортивних результатів. У деяких олімпійських видах спорту вік чемпіонів та призерів на головних міжнародних змаганнях досягає 36-42 років (серед єдиноборств), а іноді, навіть 52 років (кінний та вітрильний спорт) [1, 4].

Враховуючи, що провідною ланкою формування психоемоційних реакцій в умовах екстремальних станів $\epsilon$ психофрізіологічні функції, слід очікувати зв'язок між рівнем стресостійкості, показниками сприйняття і переробки зорової інформації та віком спортсмена.
Мета дослідження - вивчення особливостей стресостійкості до психоемоційного навантаження та сприйняття і переробки зорової інформації у елітних спортсменів різного віку.

Методи та організація дослідження. У дослідженні брали участь 19 елітних спортсменів, членів збірної команди України з греко-римської боротьби, яких було розподілено на дві вікові групи. Перша група - 12 спортсменів віком 1924 років, друга - 7 спортсменів віком 27-31 рік.

Сприйняття та обробку зорової інформації вивчали за методикою «перцептивна швидкість», яку включено до апаратно-програмного психодіагностичного комплексу «Мультипсихометр-05». Зазначена методика оцінює швидкість і точність співвіднесення геометричних фрігур з метою ідентифрікації, частиною якої $є$ тестовий сигнал (фрагмент фрігури, який становить 75 чи 50 \% цілого). 
Дана методика також досліджує структурність зорового сприйняття, здатність людини відображати загальну структуру предмета чи явища, сформовану в певний проміжок часу. Дизайн усіх тестових проб у даній методиці однаковий: у середній частині зорового поля розміщують чотири пронумеровані еталонні геометричні фрігури, які складаються з чотирьох рівних відрізків, а над ними - фрагмент фрігури (тестовий сигнал), який складається 3 двох-трьох відрізків. Завдання іспитованого полягає в тому, щоб визначити, частиною якої з даних еталонних фрігур міг би бути даний фррагмент. У відповідь натискають певну (номер еталона) цифрову клавішу спеціальної клавіатури, яка входить до складу апаратно-програмного психодіагностичного комплексу «Мультипсихометр-05» [6].

За результатами тестування визначалися такі показники: продуктивність, швидкість, точність та ефрективність. Продуктивність вказує на швидкість процесів сприйняття та мислення і залежить від рухливості нервових процесів. Чим вища продуктивність, тим вища рухливість нервових процесів і тим вища швидкість сприйняття та мислення. Відносна частота помилкових відповідей діагностує ефрективність сприйняття і мислення: чим менший цей показник, тим ефективніші дані процеси. Швидкість роботи $\epsilon$ інтегральним показником швидкості та ефективності процесів мислення та сприйняття. Високий показник швидкості означає, що процеси сприйняття та обробки інфоормації рухливі та ефективні $[7,8]$.

Для визначення врівноваженості процесів збудження та гальмування (балансу) у центральній нервовій системі нами було застосовано методику «Реакція на рухомий об'єкт». Вона становить різновид складної сенсомоторної реакції, яка крім сенсорного та моторного періодів включає період відносно складної обробки сенсорного сигналу центральною нервовою системою.

Суть завдання полягала в тому, що в кожній окремій пробі іспитованому пред'являють два сигнали - динамічний (ціль) та статичний (маркер). Останній окреслював локальну зону у просторі, при досягненні якої випробуваний повинен відреагувати своєчасним дискретним сигналом на датчик. Особливість цих двох режимів полягає у тому, що впродовж усієї проби місцеположення обох сигналів знаходиться під постійним зоровим контролем іспитованого. Вважається, що переважання збуджувальних (активаційних) процесів над гальмівними проявляється в тенденції до виконання попереджуючих дій, тоді як переважання гальмівних процесів (зниження рівня активації) призводить до підвищення дій із запізненням. За результатами тестування визначалися такі показники: точність, стабільність, збуджуваність, тренд (за збудженням). Оцінка балансу нервових процесів складається 3 двох компонентів: співвідношення випереджень і запізнень; величина і знак середньої похибки маркера від цілі в момент натискання клавіші $[7,8]$.

Рівень психоемоційної стійкості (стресостійкості) визначався за результатами «Стрес-тесту» щодо переробки інформації за позиційним вибором об'єктів у відповідних клітинах в адаптованому режимі. Так досягається певний ліміт часу для вибору об'єктів, що моделює психоемоційне інфрормаційне навантаження.

За результатами тестування визначалися такі показники: стресостійкість, пропускна здатність та імпульсивність [9].

Статистичний аналіз проводився за допомогою програмного пакета Statgraphics 5.1 (Manugistics, Inc.). 3 огляду на те що обстежувана вибірка не підпадала під нормальний розподіл за показниками, які вивчалися, було застосовано методи непараметричної статистики за допомогою критерію знакових рангових сум Вілкоксона [5]. Для демонстрації розподілу даних використовувався інтерквартильний розмах, вказуючи першу квартиль (25\% персентиль) та третю квартиль (75 \%) [5].

Результати дослідження та їх обговорення. Порівнюючи групи за результатами тесту перцептивної швидкості, слід зазначити достовірні відмінності за такими показниками, як продуктивність та ефективність (табл. 1). Це свідчить про більш високий рівень обробки інформації у першій групі та вказує на кращі можливості когнітивних функцій у спортсменів даної групи.

Отже, у спортсменів першої групи (19-24 роки) виявляється більша продуктивність зорового сприйняття та краща ефективність обробки зорової інформації порівняно із спортсменами другої групи (27-31 роки). Можна зробити висновок про наявність залежності когнітивного компонента сприйняття та обробки інформації від віку у спортсменів високої кваліфікації. Про це свідчить також кореляційний аналіз (за Спірменом): між віком та показниками перцептивної швидкості існує зв'язок. У першій групі спостерігається лише один достовірний кореляційний зв'язок між віком та швидкістю $(r=-0,37, p<0,05)$, а у другій лише один достовірний кореляційний зв'язок між віком та показником точності ( $r=-0,31$, $\mathrm{p}<0,05)$.

Аналіз даних таблиці 2 вказує на відсутність достовірної різниці за показниками точності та 
ТАБЛИЦЯ 1 - Середні значення показників перцептивної швидкості у спортсменів різних вікових груп $(n=19)$

\begin{tabular}{|c|c|c|c|c|c|c|}
\hline \multirow{2}{*}{ Показник } & \multicolumn{3}{|c|}{ Перша група ( $n=12)$} & \multicolumn{3}{|c|}{ Друга група $(n=7)$} \\
\hline & Медіана & $\begin{array}{c}\text { Нижній } \\
\text { квартиль }\end{array}$ & $\begin{array}{c}\text { Верхній } \\
\text { квартиль }\end{array}$ & Медіана & $\begin{array}{c}\text { Нижній } \\
\text { квартиль }\end{array}$ & $\begin{array}{c}\text { Верхній } \\
\text { квартиль }\end{array}$ \\
\hline $\begin{array}{l}\text { Продуктивність, } \\
\text { ум. од. }\end{array}$ & 21,50 & 18,50 & 22,00 & $19,00^{*}$ & 14,00 & 20,00 \\
\hline $\begin{array}{l}\text { Швидкість, } \\
\text { сигнал·хв }{ }^{-1}\end{array}$ & 4,39 & 3,91 & 5,10 & 4,00 & 3,17 & 4,98 \\
\hline Точність, ум. од. & 0,88 & 0,79 & 0,92 & 0,88 & 0,75 & \\
\hline $\begin{array}{l}\text { Ефеективність, } \\
\text { ум. од. }\end{array}$ & 72,84 & 54,49 & 82,80 & $66,95^{*}$ & 47,36 & 74,80 \\
\hline
\end{tabular}

${ }^{*} p<0,05$, порівняно з першою віковою групою спортсменів.

стабільності між обома групами. Це свідчить про те, що на характеристики ефективності відтворення моторних завдань на зовнішні подразники в умовах психоемоційного напруження віковий компонент суттєво не впливає.

За показником збудження виявляється достовірна різниця між спортсменами різних вікових груп (табл. 2). Згідно з наявною шкалою, середнє значення показника збудження у першій групі відповідає балансу процесів збудження та гальмування нервових процесів. У другій групі середнє значення показника збудження вказує на наявність переважання збудження у нервових процесах (табл. 2).

Таким чином, у спортсменів першої групи виявляється баланс нервових процесів збудження і гальмування, що узгоджується із наявністю більшої продуктивності зорового сприйняття та ефективності обробки зорової інфоормації порівняно зі спортсменами другої групи. Відповідно переважання процесів збудження нервових у спортсменів другої групи призводить до погіршання сприйняття та обробки зорової інформації.

Проведений кореляційний аналіз між віком та показниками балансу нервових процесів у спортсменів обох груп показав більші значення коефіцієнтів кореляції у другій групі. Так, у спортсменів першої групи коефріцієнт кореляції між віком та стабільністю становить $r=0,52, p<0,05$, тоді як у спортсменів другої $-r=0,87$, $\mathrm{p}<0,05$. Аналогічно, коефіці$\epsilon н т$ кореляції між віком та показником збудження у спортсменів першої групи становить $r=$ $=0,43, p<0,05$, тоді як $\mathrm{y}$ спортсменів другої групи $-\mathrm{r}=$ $=0,65, \mathrm{p}<0,05$.

Отже, у спортсменів високої кваліфікації вікове погіршання стану нейродинамічних функцій в умовах психоемоційного напруження $\epsilon$ не стільки послабленням аферентної частки системи сприйняття, аналізу та переробки інформації, скільки еферентної, моторної частки. Крім того, зі збільшенням віку у спортсменів зростає зв'язок між ефективністю зорового сприйняття та переробки інфоормації 3 процесами вікової інволюції [3].

За даними таблиці 3 , достовірних відмінностей між показниками загальної інтенсивності та імпульсивності у різних вікових групах не виявлено. Водночас за показником стресостійкості виявляються достовірні відмінності серед спортсменів різних вікових груп. Стресостійкість визначається за відношенням середньої пропускної здатності зорового аналізатора на початку тесту до пропускної здатності наприкінці тесту. Інакше кажучи, показник стресостійкості вказує на можливість утримання достатнього рівня пропускної здатності зорової сенсорної системи в умовах психоемоційних навантажень. На цій підставі кращий показник стресостійкості виявляється у спортсменів першої групи порівняно з другою групою (табл. 3).
ТАБЛИЦЯ 2 - Середні значення показників балансу нервових процесів у спортсменів різних вікових груп $(n=19)$

\begin{tabular}{|l|r|r|r|r|r|c|}
\hline \multirow{2}{*}{ Показник } & \multicolumn{3}{|c|}{ Перша група ( $\mathbf{n = 1 2 )}$} & \multicolumn{3}{c|}{ Друга група (n=7) } \\
\cline { 2 - 8 } & Медіана & $\begin{array}{c}\text { Нижній } \\
\text { квартиль }\end{array}$ & $\begin{array}{c}\text { Верхній } \\
\text { квартиль }\end{array}$ & Медіана & $\begin{array}{c}\text { Нижній } \\
\text { квартиль }\end{array}$ & $\begin{array}{c}\text { Верхній } \\
\text { квартиль }\end{array}$ \\
\hline Точність, ум. од. & 2,76 & 2,41 & 3,04 & 3,97 & 2,86 & 4,85 \\
Стабільність, сV & 3,28 & 3,02 & 3,96 & 3,00 & 2,55 & 4,57 \\
Збудження, ум. од. & $-0,28$ & $-1,10$ & 0,37 & $-1,27^{*}$ & $-3,60$ & 0,01 \\
\hline
\end{tabular}

* $p<0,05$, порівняно з першою віковою групою спортсменів.

ТАБЛИЦЯ 3 - Середні значення показників стресостійкості у спортсменів різних вікових груп $(n=19)$

\begin{tabular}{|c|c|c|c|c|c|c|}
\hline \multirow{2}{*}{ Показник } & \multicolumn{3}{|c|}{ Перша група ( $n=12)$} & \multicolumn{3}{|c|}{ Друга група $(n=7)$} \\
\hline & Медіана & $\begin{array}{c}\text { Нижній } \\
\text { квартиль }\end{array}$ & \begin{tabular}{|} 
Верхній \\
квартиль
\end{tabular} & Медіана & $\begin{array}{c}\text { Нижній } \\
\text { квартиль }\end{array}$ & $\begin{array}{c}\text { Верхній } \\
\text { квартиль }\end{array}$ \\
\hline $\begin{array}{l}\text { Стресостійкість, } \\
\text { ум. од. }\end{array}$ & 88,27 & 79,01 & 90,33 & $109,20^{*}$ & 102,83 & 118,35 \\
\hline $\begin{array}{l}\text { Загальна ефек- } \\
\text { тивність, ум. од. }\end{array}$ & 1,09 & 1,07 & 1,13 & 1,10 & 0,92 & 1,15 \\
\hline $\begin{array}{l}\text { Імпульсивність, } \\
\text { ум. од. }\end{array}$ & $-0,04$ & $-0,06$ & 0,00 & $-0,03$ & $-0,06$ & 0,00 \\
\hline
\end{tabular}

* $p<0,05$, порівняно з першою віковою групою спортсменів. 
ТАБЛИЦЯ 4 - Середні значення спектральних характеристик варіабельності ритму серця у спортсменів різних вікових груп у динаміці психоемоційного навантаження $(\mathrm{n}=19)$

\begin{tabular}{|c|c|c|c|c|c|c|c|}
\hline \multirow{2}{*}{\multicolumn{2}{|c|}{ Показник }} & \multicolumn{3}{|c|}{ Перша група (n = 12) } & \multicolumn{3}{|c|}{ Друга група (n = 7) } \\
\hline & & \multirow{2}{*}{$\begin{array}{c}\text { Медіана } \\
1034,25\end{array}$} & \multirow{2}{*}{$\begin{array}{c}\text { Нижній квартиль } \\
455,18\end{array}$} & \multirow{2}{*}{\begin{tabular}{|c|} 
Верхній квартиль \\
1202,70
\end{tabular}} & \multirow{2}{*}{$\begin{array}{c}\text { Медіана } \\
1009,50\end{array}$} & \multirow{2}{*}{$\begin{array}{c}\text { Нижній квартиль } \\
1008,70\end{array}$} & \multirow{2}{*}{$\begin{array}{c}\text { Верхній квартиль } \\
1156,60\end{array}$} \\
\hline Mean RR, Mc & Початок & & & & & & \\
\hline & Кінець & 901,15 & 469,90 & 995,25 & $781,40^{\star *}$ & 781,40 & 871,70 \\
\hline \multirow[t]{2}{*}{ VLF, $\mathrm{Mc}^{2}$} & Початок & 4285,00 & 1396,50 & 10839,50 & 9239,00 & 4802,00 & 10398,00 \\
\hline & Кінець & 3262,00 & 2598,50 & 8553,50 & $1722,00^{\star *}$ & 1722,00 & 1977,00 \\
\hline \multirow[t]{2}{*}{ LF, $\mathrm{MC}^{2}$} & Початок & 2405,00 & 1785,50 & 2591,00 & 2474,00 & 2428,00 & 3906,00 \\
\hline & Кінець & 1924,00 & 1558,50 & 3359,50 & 2843,00 & 1400,00 & 2843,00 \\
\hline \multirow[t]{2}{*}{$\mathrm{HF}, \mathrm{Mc}^{2}$} & Початок & 2166,00 & 1358,00 & 2697,00 & $1428,00^{*}$ & 1276,00 & 2586,00 \\
\hline & Кінець & 1199,50 & 517,00 & 2808,00 & $2843,00^{* * *}$ & 1400,00 & 2843,00 \\
\hline \multirow[t]{2}{*}{ Total } & Початок & 11856,00 & 4483,00 & 19317,00 & 14103,00 & 11294,00 & 14853,00 \\
\hline & Кінець & 5257,00 & 4430,00 & 20228,00 & $4887,00^{* *}$ & 3849,00 & 4887,00 \\
\hline \multirow[t]{2}{*}{ LF/HF } & Початок & 1,21 & 0,70 & 2,30 & $1,73^{*}$ & 1,51 & 1,90 \\
\hline & Кінець & $2,382^{\star *}$ & 1,296 & 3,96 & $8,811^{* * *}$ & 2,966 & 8,81 \\
\hline
\end{tabular}

* $p<0,05$ порівняно з першою віковою групою спортсменів.

** $p<0,05$ порівняно з початком навантаження.

Проведений кореляційний аналіз між віком іспитованих та показниками тесту на стресостійкість вказує на наявність достовірних коефіці$\epsilon$ нтів кореляції у спортсменів першої групи лише з показником стресостійкість $(r=0,42, p<$ $<0,05)$. Отриманий фокт підтверджує зв'язок віку $з$ показником стресостійкості до психоемоційних навантажень. Серед спортсменів другої групи не виявлено достовірних зв'язків віку з показником стресостійкості.

Таким чином, проведені дослідження засвідчили наявність вікового погіршання здатності зорового аналізатора до стресостійкості в умовах психоемоційного навантаження у спортсменів високої кваліфікації.

Для виявлення вікових особливостей вегетативної регуляції ритму серця у спортсменів в умовах психоемоційного навантаження було вивчено спектральні характеристики кардіоінтервалів.

Аналіз таблиці 4 засвідчив, що між групами спортсменів різного віку на початку психоемоційного навантаження існують достовірні розбіжності за показниками варіабельності ритму серця: HF та LF/HF. Достовірно вищі значення показника HF свідчать про переважання парасимпатичної активації регуляції ритму серця у спортсменів першої групи. Знижені значення показника LF/HF у молодих спортсменів вказують на оптимізацію вегетативного балансу симпатичних та парасимпатичних впливів на пазухо-передсердний вузол серця.

Психоемоційне навантаження призводить до прискорення ритму серця (Mean RR), зростання низькочастотних (VLF) та високочастотних (HF) коливань серцевого ритму у спортсменів другої групи (табл. 4). Ця обставина вказує на вплив центрального контуру регуляції ритму серця в умовах психоемоційного навантаження 3 одночасною активацією парасимпатичної ланки вегетативної регуляції та ренін-ангіотензин-альдостеронової системи. Одночасно виявляється зміщення вегетативного балансу (LF/HF) у бік симпатичної активації вегетативної регуляції кардіоінтервалів. Таким чином, для спортсменів другої групи психоемоційне напруження викликає значні зміни у регуляції варіабельності ритму серця, що вказує на стресовий характер навантаження.

У спортсменів першої групи спостерігаються лише зміни показника вегетативного балансу (LF/HF), що вказує на посилення симпатичної активації регуляції ритму серця, але абсолютні значення змін, порівняно зі спортсменами другої групи, в два рази менші (табл. 4). Це вказує на оптимальну реакцію системи регуляції ритму серця на психоемоційне навантаження.

\section{Висновки:}

1. Виявлено зв'язок між віком елітних спортсменів та стресостійкістю до психоемоційних навантажень. Зокрема, це відображається у значних змінах регуляції ритму серця у спортсменів другої групи порівняно зі спортсменами першої групи, де спостерігається оптимальна реакція системи регуляції ритму серця на психоемоційне навантаження.

2. Виявлено погіршання нейродинамічних функцій в умовах психоемоційного напруження у спортсменів другої групи порівняно з першою за рахунок вікового послабленням аферентної частки системи сприйняття, аналізу та переробки інфоормації. 


\section{Литература}

1. Баевский Р. М. Классифрикация уровней здоровья с точки зрения теории адаптации / Р. М. Баевский // Вест. PAMH CССР. - 1989. - № 8. - С. 73-78.

2. Зильберман П. Б. Эмоциональная устойчивость оператора / П. Б. Зильберман // Очерки психологии труда оператора / под ред. Е. А. Милеряна. - М.: Наука, 1974. - C. $138-172$.

3. Коробейников Г. В. Психофизиологические механизмы умственной деятельности человека / Г.В.Коробейников. К.: Україн. фрітосоціологіч. центр, 2002. - 123 с.

4. КоробейникоВ Г. В. Физиологические механизмы мобилизации функциональных резервов организма человека при напряженной мышечной деятельности / Г. В. Коробейников // Физиология человека. - 1995. - Т. 21, N 3. - С. 81-86.

5. РеброВа О. Ю. Описание процедуры и результатов статистического анализа медицинских данных в научных публикациях / О. Ю. Реброва // Междунар. журн. медицин. практики. - 2000. - № 4. - С. 43-46.

6. Korobeynikov G. Psychophysiological states and motivation in elite judokas / G. Korobeynikov, K. Mazmanian, W. Jagello // Archives of Budo Science of Martial Arts. 2010. - Vol. 6. - P. 129-136. /www.archbudo.com.

7. Collardeau M. Single and choice reaction time during prolonged exercise in trained subjects: influence of carbohydrate availability / M. Collardeau, J. Brisswalter, F. Vercruyssen, M. Audiffren, V. Goubault // Eur. J. Appl. Physiol. 2001. - N 86. - P. 150-156.

8. Van der Molen M. W. Energetics and the reaction process: Running threads through experimental psychology / M. W. Van der Molen // Handbook of perception and action / Eds. O. Neumann \& A. F. Sanders. - 1996. Vol. 3. - P. 229-276.

9. Dornic S. A high-load information-processing task for stress research / S. Dornic, V. Dornic // Percept. \& Mot. Skills. - 1987. - Vol. 65, N 3. - P. 712-714.

\section{Reference}

1. Baevskiy R. M. Classification of health level in view of adaptation theory / R. M. Baevskiy // Vesnik RAMN USSR. - 1989. - N 8. - P. 73-78.

2. Zilberman P. B. Emotional stability of operator / P. B. Zilberman // Essays on industrial psychology of operator / in edition of E. A. Milerian. - Moscow: Nauka, 1974. - P. 138-172.

3. Korobeynikov G. V. Psychophysiological mechanisms of human mental activity / G. V. Korobeynikov. - Kiev: Ukrainian fitosociological center, 2002. - 123 p.

4. Korobeynikov G. V. Physiological mechanisms of mobilization of functional reserves of the human body during intense muscular activity / G. V. Korobeynikov // Human Physiology. - 1995. - Vol. 21, N 3. - P. 81-86.

5. Rebrova $O$. U. Description of the procedure and the results of the statistical analysis of medical data in scientific publications / O. U. Rebrova / / International Journal of medical practical. -2000 . - N 4. - P. 43-46.

6. Korobeynikov G. Psychophysiological states and motivation in elite judokas / G. Korobeynikov, K. Mazmanian, W. Jagello // Archives of Budo Science of Martial Arts. 2010. - Vol. 6. - P. 129-136. /www.archbudo.com.

7. Collardeau M. Single and choice reaction time during prolonged exercise in trained subjects: influence of carbohydrate availability / M. Collardeau, J. Brisswalter, F. Vercruyssen, M. Audiffren, V. Goubault // Eur. J. Appl. Physiol. 2001. - N 86. - P. 150-156.

8. Van der Molen M. W. Energetics and the reaction process: Running threads through experimental psychology / M. W. Van der Molen // Handbook of perception and action / Eds. O. Neumann \& A. F. Sanders. - 1996. Vol. 3. - P. 229-276.

9. Dornic S. A high-load information-processing task for stress research / S. Dornic, V. Dornic // Percept. \& Mot. Skills. - 1987. - Vol. 65, N 3. - P. 712-714. 